International Journal of Child, Youth and Family Studies (2015) 6(3): 478-493

\title{
HOMELESS YOUNG ADULTS IN THE SWISS SOCIAL ASSISTANCE SYSTEM: EVALUATION OF AN INSTITUTION FOR HOMELESS YOUNG ADULTS WHO HAVE NO DAILY STRUCTURE
}

\section{Renate Stohler and Milena Gehrig}

\begin{abstract}
This article presents an evaluation study of a home for young adults who have lost their accommodation. Most of the home's residents are found to have unstable biographies as to housing and education as well as a history of psychological problems and substance abuse. The programme is successful for those who have a daily structure, but fails those who do not, or with psychological problems or drug addiction. An integrated approach is recommended and the accessibility of services questioned.
\end{abstract}

Keywords: Transition to adulthood, homelessness, housing, labour market integration, accessible services, evaluation.

Renate Stohler, is researcher and lecturer at the School of Social Work, ZHAW Zurich University of Applied Sciences, Pfingstweidstrasse 96, P.O. Box 707, 8037 Zurich, Switzerland. Tel: (41) 5893488 67. Email: renate.stohler@zhaw.ch

Milena Gehrig, is research associate at the School of Social Work, ZHAW Zurich University of Applied Sciences, Pfingstweidstrasse 96, P.O. Box 707, 8037 Zurich, Switzerland. Tel: (41) 5893488 57. Email: milena.gehrig@zhaw.ch 
International Journal of Child, Youth and Family Studies (2015) 6(3): 478-493

\section{Problem identification}

The transition from youth to adulthood can be seen as "status passage in the institutionalised life course” (Buchmann \& Kriesi, 2011, p. 482), which is characterised by several transitional events such as completion of mandatory school and vocational training, entry into the labour market, leaving the parental home and starting a family (Buchmann \& Kriesi, 2011). Buchmann and Kriesi further state that living independently and economically while being socially integrated are central attributes of adulthood and therefore socially desired objectives, which young and healthy individuals are expected to fulfil. Becoming an adult is a highly complex process whose outcomes depend not only on individual resources but also "largely on the structural opportunities and constraints" (p. 482).

High and increasing rates of youth unemployment in European countries indicate that there are vulnerable groups of young adults, whose integration is at risk. This is especially true for young men and women who are not employed or undergoing education or training; they are called NEET (a young person who is Not in Education, Employment, or Training). Therefore the transition from school to work is one of the key topics of social policy and social research in Europe. Although in Switzerland the youth unemployment rate is quite low in comparison to other European countries (Organisation for Economic Cooperation and Development [OECD], 2013) the national statistics on public assistance shows that young adults are overrepresented among the social assistance recipients (Bundesamt für Statistik [BFS], 2009). Therefore, there has been an increasing awareness of the precarious circumstances and exclusion risks of young adults in Switzerland since the 1990s and various services to support labour market integration have been implemented (BFS, 2009; Schaffner \& Drilling, 2013).

Although often not explicitly mentioned, a safe and stable place of residence is an important prerequisite in the process of becoming an adult. Inadequate housing options or homelessness can prevent young men and women from completing an education or from going to work regularly. Therefore an unstable housing situation can jeopardise the integration of young adults into the labour market and hence into society. The consequences of an insufficient integration can be dependency on welfare, homelessness, destitution, and reduced possibilities of participation. The housing situation of young adults can influence their success in completing upper secondary education and therefore their integration into the labour market just as the absence of a daily structure (through further education or employment) can reduce their chances of finding an adequate accommodation. Therefore, young adults without a stable place to live and no daily structure are at high risk of failing in the transition from youth to adulthood, that is, to live independently.

In this article, the situation of this group of young adults is examined more closely.

The literature review focuses on three primary areas in order to establish an understanding of the situation of young adults in Switzerland in general and also of the 
International Journal of Child, Youth and Family Studies (2015) 6(3): 478-493

specific situation of young adults without stable accommodation and daily structure. The three areas are: (a) the qualification and labour market situation of young adults, (b) the situation of young adults who receive social welfare, and (c) the housing situation of young adults including an overview of institutions that offer housing to young adults. Our main purpose is to present and discuss the results of an evaluation study of a programme that supports young adults who live under precarious circumstances and do not have a stable accommodation or a daily structure.

\section{The legal situation and social security system in Switzerland}

In view of the human right of every person to enjoy access to education, without discrimination or exclusion (Article 26) and the human right to "a standard of living adequate for the health and well-being of himself and of his family, including food, clothing, housing and medical care and necessary social services, and the right to security in the event of unemployment, sickness, disability, widowhood, old age or other lack of livelihood in circumstances beyond his control” (Article 25) promoted by the United Nations (2014) and UNESCO (1960), the homelessness of young adults and their resulting exclusion from further education and employment must be taken seriously.

In Switzerland children and young people have the right to special protection of their integrity and to the encouragement of their development (Article 11, BV) ${ }^{1}$ and to free basic education (Article 19, BV). Furthermore, everybody who is unable to provide for himself or herself has a right to help in situations of need (Article 12, BV). In contrast to other European countries, Switzerland does not formally acknowledge a right to housing, but the state is responsible for providing sufficient housing facilities (Article 108, BV) (Gysi, 2013).

The Swiss social security system is based on various insurance schemes providing insurance against the major life risks such as old age, invalidity, or unemployment. Furthermore, social assistance serves as a last-resort safety net (Federal Social Insurance Office, 2014). Social assistance, which is financed by public funds, is based on the subsidiarity principle and comes into effect when there are no other financial means (personal capital, contributions from social insurance, and support from relatives) and a concrete individual financial plight can be proved (Stadt Zürich, 2014).

The fragmentation of the social security system has so far caused planning and actions to be primarily influenced by the jurisdiction instead of the aim of achieving the highest possible integration for those affected. In order to improve the integration of unemployed individuals into the labour market and avoid revolving doors and unnecessary duplication, efforts have been made for a number of years now to improve the inter-institutional cooperation between unemployment assistance, invalidity assistance, and social assistance (Nationale IIZ Koordinationsgruppe, 2004). With regard to young adults, the efforts to ensure inclusion are mostly based on education and employment and often do not consider other aspects of inclusion (Nadai, 2013; Knöpfel, 2013). The fragmentation of the social security system complicates a holistic approach to

\footnotetext{
${ }^{1}$ Constitution of the Swiss Federal State from 18th April 1999 (stand at 3rd March 2013).
} 
International Journal of Child, Youth and Family Studies (2015) 6(3): 478-493

integration, which would take into account all aspects of integration into society of the affected person.

\section{Literature Review}

\section{Education and employment of young adults in Switzerland}

In recent years social change and globalisation have strongly affected the labour market in Switzerland (Friedrich, 2014, p. 15) and therefore also the school-to-work transition of young people, that is, the transition from youth to adulthood (Schaffner, 2007; Schaffner \& Drilling, 2013).

Nowadays a post-compulsory education is the basis of a stable and long-term integration into the labour market. The statistics show that there is a higher risk for unqualified people of becoming unemployed or living on social welfare than for those with training. Therefore, since 2006 it has been the declared aim of Switzerland's education policy that, by 2015, 95\% of the 25-year-olds should have completed upper secondary education, which is further education after compulsory education corresponding to education level 3 of the ISCED Scale (EVD, EDI, \& EDK, 2011). A qualification in upper secondary education provides both access to the next level of education and trains young adults to be qualified workers, and is seen as the minimum requirement to successfully compete in the labour market (BFS, 2013a).

Since high expectations concerning one's willingness to pursue education after compulsory schooling to enhance employability has become the norm, while at the same time structural changes cause a shortage of education and training opportunities, the transition from youth to adulthood involves new risks (Gazareth, Juhasz, \& Magnin, 2007, as cited in Schaffner \& Gerber, 2014).

In Switzerland the majority of young people start a post-compulsory education (secondary II) after completing mandatory school. The post-compulsory education system distinguishes between vocational training for direct entry into the labour market and higher secondary school that prepares for tertiary education (Schweizer Medieninstitut für Bildung und Kultur, 2011).

In 2011 the majority (about 60\%) of young men and women started a vocational training in the first year after leaving mandatory school (Schweizerische Koordinationsstelle für Bildungsforschung, 2014). But since 2005, about one-fourth of the school leavers have not directly started post-compulsory education and thus have ended up doing internships or interim years to try and enter compulsory education a year later, which has been achieved by 70\% (Schweizerische Koordinationsstelle für Bildungsforschung, 2014). Other young adults start a further education programme, which they change or quit after the first or second year. In a nutshell, the available data reveal that the educational career after compulsory education for $45 \%$ of school leavers is characterised by discontinuation such as changes, interruption, and repetitions (Meyer, 2009). In 2011, a total of 95.3\% of young adults in Switzerland at the typical age of 
International Journal of Child, Youth and Family Studies (2015) 6(3): 478-493

finishing upper secondary education actually graduated on that level, 24\% of whom finished a general education (intermediate education or general qualification for university entrance "Matura") and 71.3\% vocational education and training (VET), which is a dual apprenticeship training that can be done with or without a "Matura" degree to gain access to tertiary education (BFS, 2013b).

Consequently a group of about $5 \%$ of young adults remain without postcompulsory qualification although various services to support the integration of young people into the labour market have been implemented in Switzerland over the last 20 years (Egger, Dreher, \& Partner AG, 2007). In Switzerland there is a strong relationship between social background and school success and therefore school leavers with poor school performance and from socially and economically disadvantaged families are at a higher risk of remaining without a post-compulsory education (Moser, 2004; Meyer, 2005; Schultheis, Perrig-Chiello, \& Egger, 2008; Suter \& Höpflinger, 2008) and being unemployed or becoming dependent on social welfare (BFS, 2009). Although only few studies on the situation of young people leaving care have been conducted, there is some evidence indicating that they should be regarded as a vulnerable group that also is at a higher risk of exclusion (Gabriel \& Stohler, 2008, 2012). In a meta-analysis of 59 studies on vocational education of young people at risk, Häfeli and Schellenberg (2009) focus on success factors that must be taken into account when developing support services. The study identifies about 50 success factors in seven areas (personal, family, school and teachers, workplace and professional trainers, advisory and intervention services, leisure time and peers, and society (Häfeli \& Schellenberg, 2009).

As already mentioned above, young adults have been overrepresented among the unemployed and among the social welfare beneficiaries since 1990 (Bundesamt für Statistik, 2009). In Switzerland, unemployed adults who are not or no longer entitled to unemployment benefits and who are at risk of poverty receive social assistance. Young recipients of social assistance are regarded as a highly vulnerable group with poor prospects for the future (Bundesamt für Statistik, 2009). Therefore, since 1990 the transition to adulthood of young people at risk has been investigated in several studies (Schaffner \& Drilling, 2013).

Based on the national social welfare statistics, the situation of young social welfare recipients (aged 18 to 25) was analysed in detail for the first time (Bundesamt für Statistik, 2009). With regard to education, the analysis revealed that $51 \%$ of these young adults did not have a secondary-level degree and were also not undergoing education at the time, whereas $23.6 \%$ were completing an education, $24.9 \%$ had finished an education on a secondary level, and only $0.5 \%$ had earned a bachelor or master's degree (BFS, 2009).

The results of the analysis also indicate that the risk of needing welfare assistance is dependent on the system transitions (school-to-work and education-to-labour market) and there is also some evidence suggesting that the young adults' coping options are influenced by the socio-economic situation of the parental home (BFS, 2009).

Another study on young adults (aged 18 to 24) receiving social assistance in Basel gives a very detailed picture of the young people's social situation that generally 
International Journal of Child, Youth and Family Studies (2015) 6(3): 478-493

complies with the analysis of the national statistics (Drilling, 2004). In addition, the study indicates that the young men women often had conflicts or problems with their families or parents and about $15 \%$ had had experience with child and youth care services when they were minors (Drilling, 2004; Schaffner \& Drilling, 2013).

The qualitative analysis of education biographies of young social welfare recipients by Schaffner (2007) showed that reaching legal age was a critical event in the lives of the interviewed young adults. When they turned 18, almost all young men and women had taken or wanted to take full responsibility for their own lives. Most of them had to live independently because they moved out or were thrown out from their parental home, left residential or foster care, or immigrated into Switzerland without their families. Living independently with little experience and no support caused various problems of coping with daily life in terms of work, food, housing or money, for example; therefore most of the young adults were not able to complete their training or apply for a job (Schaffner \& Drilling, 2013) and became dependent on social welfare. Schaffner (2007) found out that the behaviour of these young people has to be regarded as manifestations of developmental coping problems, which are hardly taken into account by the social welfare system (Schaffner \& Drilling, 2013).

Inappropriate coping strategies for mastering the challenges of an independent life can have serious consequences for young people such as dropping out of a postcompulsory education course, becoming unemployed due to lack of reliability, or losing their accommodation.

\section{Housing situation and homelessness}

With the aim of obtaining a better picture of the situation of young adults in Europe, several studies have focused on the housing situation of young adults examining the age of leaving the parental home. In 2008, approximately $46 \%$ of young adults (51 million) between 18 and 34 years of age still lived with at least one of their parents, 33 million of whom were aged between 18 and 24. In all of the European Union, 13\% of young adults aged 18 to 34 living in the same dwelling as at least one of their parents were identified to be at risk of poverty. However, living in the parental home can decrease the total risk of poverty.

A key factor affecting the decision of young adults to leave their parental home is having a partner, while staying in education, working on temporary contracts, or being unemployed are reasons to stay with the parents for a longer time (Choroszweicz \& Wolff, 2010). The percentage of young adults in Switzerland living at their parents' home is not much different from the situation in the EU. The age of young women leaving parental home and starting a family is between 20 and 30 years, while young men take that step between the ages of 22 and 32 (Höpflinger \& Perrig-Chiello, 2008). An analysis of the Swiss Labour Force Survey revealed that in 2004, 80\% of young adults (aged 18 to 24) lived with at least one of their parents (Höpflinger \& Perrig-Chiello, 2008). 
International Journal of Child, Youth and Family Studies (2015) 6(3): 478-493

While at what age young adults leave their parental home in Europe has been exhaustively studied, data about the current housing situation of young adults are scarce. Housing opportunities vary from living with the parents, living in a single household, living independently in a shared accommodation, living in residential or foster care providing supported long-time accommodation and temporary shelter, and homelessness. In the 1990s, homelessness of children and young adults was discussed in the media in Germany (Mücher, 2010) and also in Switzerland (Gabriel, Stohler, Aeschbacher, Lörincz, \& Lang, 2004).

In Switzerland the number of young homeless people is unknown but estimated to be low. In a survey of child- and youth-care institutions, 64 children, youths, and young adults (aged 13 to 25) who lived on the street permanently or over a longer time period could be identified in Zürich in 2004. About half of them were 16 or 17 years old (Gabriel et al., 2004). From the perspective of the interviewed social workers, the young people had various problems, but family conflicts and domestic violence were regarded as the most important reasons for living on the street (Gabriel et al., 2004).

In 2010, there were reports in the media about young adults seeking refuge in shelters for homeless people in the major Swiss cities. For example, in Berne 25 young adults aged 18 to 25, mostly from a migrant background and affected by poverty, were reported to be living in such a shelter (Berner Zeitung, 2010). Homeless young people are not considered an urgent social problem because there are only a few such cases in Switzerland, which is attributed to the well-developed child- and youth-care system (Excerpt from the minutes of the Zurich Cantonal Council's meeting on February 6, 2013).

The statement, "We don't talk about housing, we just do it [author's translation]" (Löpfe \& Moser, 2012, p. 11) describes the common socio-political way of understanding and treating the topic of housing. Housing and the housing environment affect individual development opportunities. Therefore, a disadvantage in the housing situation may lead to further disadvantages in other areas of life such as unemployment, poverty, homelessness, inferior education opportunities, and health (Brändle-Ströh, 1999, as cited in Gysi, 2013), which affect different areas of social work. But despite this, there is no focus on adequate housing in social politics. As mentioned before, the efforts to ensure the integration of young adults are mostly education-based or employment-based, which is apparent in various existing programmes that support labour integration.

Although there are countless institutions offering help to homeless people (Wolf, 2011), a closer look at the numerous institutions in the canton of Zurich that offer housing for young healthy adults without disabilities shows that an existing external daily structure generally is a prerequisite for admission. Most of the long-term housing facilities only take in young adults enrolled in a post-compulsory education programme. Several institutions for long-term housing focus on young adults with a disability or a psychological illness and require a certified need for assistance and care or an official declaration of entitlement to disability insurance. Institutions offering accommodation for young people without any restrictions are considered short-term shelters in situations of emergency. They do not offer any daily structure or focus on employment integration, 
International Journal of Child, Youth and Family Studies (2015) 6(3): 478-493

nor do they specialise in young adults. In view of the shortage of institutions specialising in young adults and offering accommodation that goes beyond short-term shelter, and that also takes in young adults without any daily structure and/or a certified need for assistance and care, a few institutions that focus on that target group have been established in Switzerland in the recent years.

\section{The Present Study}

\section{Background}

In 2009, a new concept for a home for young adults with no housing facility, no daily structure, and other multiple problems was established in a Swiss city. Its target group are young adults, aged 18 to 24, without a stable dwelling. The young men and women can neither live with their family nor independently and do not want to live in residential care or in a foster family. Furthermore, they have little or no daily structure and often have debts, are psychologically unstable and consume marijuana or alcohol.

The home is designed to be a voluntary transitional opportunity offering shared accommodation for a total of 28 young men and women. Housekeeping and food has to be arranged independently (and individually). Allocation to the institution is done by the case management of the social assistance service; assistance and regular status reviews (progress reviews) are the responsibility of the individual reference person of the institution. While the reference person's primary task is giving advice and assistance, the case manager from the social assistance service is given more responsibility to make decisions and impose sanctions.

\section{Institution objectives and research questions}

The main objective of the institution and also the indicator of the institution's effectiveness is the young adults' integration in a long-term living solution within 12 months. Further objectives are to strengthen social and personal competence, stabilise the situation and prevent further harm. In this evaluation study, the achievement of the main objective of the institution, integration in a long-term living solution, was examined. The research questions were the following:

1. What effect does the institution have and which problem constellations have a positive effect on the achievement of the main objective?

2. What are the difficulties in the cooperation with placing institutions and how can the cooperation between the case management of the social assistance service and the social worker of the institution be optimised?

\section{Method}


International Journal of Child, Youth and Family Studies (2015) 6(3): 478-493

Within a qualitative study design, several perspectives and various approaches to collect data were included. All former inhabitants who left the institution between January 2011 and January 2012 were contacted by the institution. Out of the 14 young adults who agreed to participate, six contrasting cases were selected. About half a year after the subjects left the organisation, face-to-face interviews were conducted with the aim of portraying the experiences and perspectives of the young adults as well as collecting information about the process after leaving the institution and about their current situation. In order to gain insight into the former biographies and problems of the young adults, the files from the selected former residents were analysed. Moreover, guided telephone interviews with the case managers from the social assistance services ( $n$ $=6)$ and a group discussion with the staff of the institution $(n=5)$ were held to include the experts' experience with the institution and their estimation of the effects both from an outside and an inside point of view.

The data gathered was assessed by means of content analyses (Mayring, 2008). Common points and differences, across the different data sources, have been identified, evaluated, and discussed.

\section{Results}

The focus of the analysis was put on four primary topics: the young adults' history, the reason for their entrance into the institution, the process during their stay in the institution, and the effects of the institution from both short- and long-term perspectives.

Regarding the history of the former inhabitants of the institution (data from file analysis and interviews), it is noticeable that all of them have very unstable housing biographies with stays at different institutions combined with living with different family members $(n=3)$ or several stays at different institutions combined with stays with the mother $(n=2)$. Apart from one person, all subjects have had experience with child- and youth-care institutions (i.e., they were in temporary residential care or boarding school and returned to their parental home). Just one person continuously lived at his or her mother's place.

In most of the cases, the transition from compulsory to upper secondary education has not been successful (i.e., they dropped out of vocational education and training or an interim solution, or they had not yet managed to find a vocational education). Only two persons succeeded in the transition from compulsory to upper secondary education and were enrolled in a vocational education programme or temporarily employed before starting a vocational education course prior to entering the institution.

Other noticeable aspects of the subjects' histories are psychological problems and the consumption of cannabis and/or alcohol, which is mentioned in the majority of the files.

The main reason why the young adults entered the institution was that they had been made to leave their parental home mainly due to arguments or because their apprenticeship had been terminated. Some of them did not have any employment at all. Thus the main reason for being homeless or living in an instable situation is the absence 
International Journal of Child, Youth and Family Studies (2015) 6(3): 478-493

of a daily structure. Only two of the young adults were doing an apprenticeship or had a job as an interim solution until the apprenticeship started: In one of these cases, arguments in the context of the mother's alcohol addiction and in the other case financial difficulties - and thus inability to pay the rent due to the sudden absence of the mother were the reason for entering the institution. None of the young adults had an alternative possibility of accommodation.

Based on the various data sources, the extent to which the programme's main objective (integration in a long-term housing solution within 12 months) and the further objectives (strengthening social competences and personal competence, stabilising the situation, and preventing further harm) have been reached has been assessed. The data indicate that the programme provides safety and support in case of endangerment; it enables the young adults to gain distance from their parental home and focus on their own person; social competences, personal competences, and housing competences are strengthened, and professional orientation as well as professional integration of the young adults are promoted. Most of the young adults later transferred to an agreeable housing solution, which, however, in some cases was an emergency or interim solution. Two of the young adults dropped out of the programme because they had repeatedly violated internal rules and or the law. The programme has therefore reached its further objectives, whereas the main objective, which was the integration in a long-term housing solution within 12 months, has not been reached in all cases.

As a stable integration into society requires residential integration as well as employment integration, the effect of the programme on both aspects of integration at the time when the young adults left the programme and at the time the interviews with the former inhabitants were conducted (5 to 11 months after leaving the programme) is examined more closely.

All young adults who left the programme in a regular manner $(n=4)$ had both a follow-up housing solution (with one parent, with relatives, or in a girlfriend's family) and a job or an apprenticeship when leaving the programme. At the time of the interview (5 to 11 months after leaving the programme) all young adults who left the programme in a regular manner still had accommodation even though two persons had moved out from their follow-up solution (one person had moved into another shared accommodation and another person now had his own flat). Regarding the labour market integration, in two cases some progress was observed (from the apprenticeship to fixed long-term employment and from a temporary job to an apprenticeship); two young adults, however, lost the jobs they had had when leaving the programme. Both of them are facing trouble at their current place of living due to their unemployment and the resulting lack of a daily structure and financial difficulties.

It is remarkable that those young individuals who already had a job when entering the programme proved themselves in the labour market after leaving the programme. Although all young adults who had lost their apprenticeship prior to entering the programme were able to find a new apprenticeship or temporary job, 5 to 11 months after leaving the programme they had lost their jobs again. 
International Journal of Child, Youth and Family Studies (2015) 6(3): 478-493

Of the two young adults who quit the programme in an irregular manner, one person was homeless at the time of the dropping out and the other was taken into custody. Although both of them made some efforts towards their professional integration during their participation in the programme, neither of them succeeded in acquiring employment. At the time of the interview (5 to 11 months after dropping out of the programme), one of the young adults still did not have a permanent accommodation or a job. In the other case, however, some progress had been achieved both in terms of residential and of work integration as this person has joined an assisted youth group and started an apprenticeship. Considering the two cases of irregular discharge, it can be noted that both of them had already had multiple problems (with the daily structure, no training or workplace, mental health issues) before entering the programme and disobeyed the rules required for staying in the programme.

Overall, it can be ascertained that the programme is suitable for young people who already have a daily structure or can be adapted into one, who are independent and willing to change their situation. However, the programme is inappropriate or unsuccessful for young people who do not strive to change their situation, are not cooperative, suffer from psychological problems or drug addiction, have never worked before or have had problems with their daily structure for a long time or repeatedly dropped out of suitable programs. For young people with such multiple problems, it is difficult to find an adequate solution; moreover, they find it difficult to adhere to the requirements for staying in the programme.

The measured effect of the programme depends on the indicators and on the time of the measurement. If only the main objective of the programme, namely the residential integration when leaving the programme, is considered, four persons were successfully integrated whereas 5 to 11 months later five people were successfully integrated into the housing market. Regarding the professional integration, four persons had succeeded in finding a job when leaving the institution; 5 to 11 months later only three persons were still successfully integrated in an education programme, training, or job. Thus, while the residential integration appears to be more stable in the long-term perspective, it can be jeopardised due to a setback in the work integration.

\section{Conclusion}

The results of this study raise various t questions at different levels. On the one hand the indicator of the programme's effectiveness can be called into question. If only the main objective of the programme, namely the young adults' integration in a long-term living solution within 12 months, is considered for measuring the programme's effectiveness, other case-related progress or reversals at other levels (e.g., strengthening social and personal competence) remain invisible. Considering that social integration is based both on residential as well as on labour-market integration, focusing on only one outcome or goal is too narrow. Therefore we maintain that indicators in the area of employment should be taken into account when evaluating the effectiveness of the programme. 
International Journal of Child, Youth and Family Studies (2015) 6(3): 478-493

The second question is whether the limited stay of 12 months meets the needs of the young men and women. This study shows that already achieved successes may not be stable in a long-term perspective, especially if addressing labour market integration. It can therefore be assumed that already achieved successes could be stabilised through a prolonged stay.

As well, it can be assumed that due to the complex problems of young adults a stay of more than one year in the institution may be needed to achieve the agreed goals for some young men and women. Therefore a length of stay that is adapted to the individual needs could perhaps improve the impact of the programme's sustainability.

At the level of the individual case, the study suggests that the programme is inappropriate for young people with serious problems of acclimating themselves to a daily structure, with multiple burdens, and with hardly any social network. Often these young people are not able to comply with the requirements of the institution because they have - as Schaffner (2007) shows - never learned to master important developmental tasks and resort therefore to strategies which do not agree with the rules of the institution. As a matter of fact it has to be asked what sort of assistance these young people need in order to enable them to solve the developmental tasks. The challenge for the institution is to provide an open structure, which is accepted by the young adults, as well as to guaranteeing enough support to build up a daily structure. Young social assistance recipients are regarded as a challenge for educational, social, and labour market policy (Schaffner \& Drilling, 2013). There is a need for early interventions with children and youth at risk and their families in order to prevent exclusion. Because of the interdependency of residential and labour market integration, an integrated approach is required. Further, the strengthening of self-competence and of the social networks should be identified goals of the program (Böhnisch, 1999). Therefore high quality case work, which is supported by inter-institutional cooperation in the areas of education, employment, and social assistance, is needed. 
International Journal of Child, Youth and Family Studies (2015) 6(3): 478-493

\section{References}

Berger, F. (2009). Auszug aus dem Elternhaus. Strukturelle, familiale und persönlichkeitsbezogene Bedingungsfaktoren. In H. Fend, F. Berger, \& U. Grob (Eds.), "Lebensverläufe, Lebensbewältigung, Lebensglück. Ergebnisse der LifEStudie" (pp. 195-243). Wiesbaden: VS. http://dx.doi.org/10.1007/978-3-531-91547-0_8

Berner Zeitung. (2010). Berner Obdachlose werden immer jünger. Berner Zeitung. 20.06.2010.

Bundesamt für Statistik (BFS). (2009). Junge Erwachsene in der Sozialhilfe. Neuchâtel.

Bundesamt für Statistik (BFS). (2013a). Abschlüsse und Kompetenzen - Abschlussquote auf der Sekundarstufe II (ISCED 3) IV. Retrieved from: http://www.bfs.admin.ch/bfs/portal/de/index/themen/ 15/17/blank/02.indicator.415101.4035.html.

Bundesamt für Statistik (BFS). (2013b). Abschlussquote der Sekundarstufe II 1990-2011. Statistik des jährlichen Bevölkerungsstandes, 1981-2009. Neuchâtel.

Böhnisch, L. (1999). Sozialpädagogik der Lebensalter. Weinheim: Juventa.

Buchmann, M. C., \& Kriesi, I. (2011). Transition to adulthood in Europe. Annual Review of Sociology, 37, 401-503. doi: abs/10.1146/annurev-soc-081309-150212

Choroszweicz, M., \& Wolff, P. (2010). 51 million young EU adults lived with their parent(s) in 2008. Eurostat Statistics in focus, 50, 1-11.

Drilling, M. (2004). Young urban poor. Abstiegsprozesse in den Zentren der Sozialstaaten. Wiesbaden: Verlag für Sozialwissenschaften. http://dx.doi.org/10.1007/978-3-322-80571-3

Egger, Dreher \& Partner AG. (2007). Vertiefungsstudie Bildungsangebote im Übergang von der obligatorischen Schule in die Berufsbildung. Erstellt im Auftrag des Bundesamtes für Berufsbildung und Technologie. Bern.

Eidgenössisches Volkswirtschaftsdepartement (EVD), Eidgenössisches Departement des Inneren (EDI), \& Schweizerische Konferenz kantonaler Erziehungsdirektoren (EDK). (2011). Chancen optimal nutzen. Erklärung 2011 zu den gemeinsamen bildungspolitischen Zielen für den Bildungsraum Schweiz. Schweizerische Eidgenossenschaft, Bern. Retrieved from: http://www.edk.ch/dyn/11665.php 
International Journal of Child, Youth and Family Studies (2015) 6(3): 478-493

Federal Social Insurance Office, Switzerland. (2014). Social security in Switzerland. Retrieved 12.03.2014 from http://www.bsv.admin.ch/themen/ueberblick/00003/index.html?lang=en

Friedrich, C. (2014). Bericht über die soziale und wirtschaftliche Entwicklung in der Schweiz 2012/2013. In Caritasb (Ed.), Sozialalmanach 2014. Schwerpunkt: Unter einem Dach (pp. 13-57). Luzern: Caritas-Verlag.

Gabriel, T., \& Stohler, R. (2008). Transitions to adulthood of young care leavers in Switzerland. In M. Stein \& E. R. Munro (Eds.), Young people's transition from care to adulthood. International research and practice (pp. 197-208). London: Kingsley.

Gabriel, T., \& Stohler, R. (2012). Lebenswege nach einer Heimerziehung in der Schweiz. In B. Tänzler (Ed.), Kinderheim statt Kinderzimmer. Neun Leben danach (pp. 133-141) Zürich: Helden-Verlag.

Gabriel, T., Stohler, R., Aeschbacher, B., Lörincz, A., \& Lang, K. (2004): Kinder und Jugendliche auf der Strasse ? Pilotstudie in der Stadt Zürich im Auftrag der Jugendseelsorge Zürich - Katholische Arbeitsstelle für Jugendarbeit und Jugendberatung im Kanton Zürich.

Gazareth, P., Juhasz, A., \& Magnin, C. (2007). Neue Soziale Ungleichheit in der Arbeitswelt. Konstanz: UVK Verlagsgesellschaft GmbH.

Gysi, S. (2013). Wohnen in der Schweiz. In A. M. Riedi, M. Zwilling, M. Meier Kressig, P. Benz Bartoletta, \& D. Aebi Zindel (Eds.), Handbuch Sozialwesen Schweiz (pp. 119-130). Bern: Haupt Verlag.

Häfeli, K., \& Schellenberg, C. (2009). Erfolgsfaktoren in der Berufsbildung bei gefährdeten Jugendlichen. Schweizerische Konferenz der kantonalen Erziehungsdirekteren (EDK).

Höpflinger, F., \& Perrig-Chiello, P. (2008): Junges Erwachsenenalter: Auszug aus dem Elternhaus und Familiengründung. In P. Perrig-Chiello, F. Höpflinger, \& C. Suter (Eds.), Generationen - Strukturen und Beziehungen. Generationenbericht Schweiz. Synthesebericht des Nationalen Forschungsprogramms 52, "Kindheit, Jugend und Generationenbeziehungen in einer sich wandelnden Gesellschaft" (pp. 145-164). Zürich: Seismo Verlag. 
International Journal of Child, Youth and Family Studies (2015) 6(3): 478-493

Knöpfel, C. (2013). Sozialpolitik mit Zukunft. Eine kritische Analyse der dominanten Diskurse. In A. M. Riedi, M. Zwilling, M. Meier Kressig, P. Benz Bartoletta, \& D. Aebi Zindel (Eds.), Handbuch Sozialwesen Schweiz (pp. 428-437). Bern: Haupt Verlag.

Löpfe und Moser. (2012). Wohnen. SozialAktuell, 11, 11.

Mayring, P. (2008). Qualitative Inhaltsanalyse. Grundlagen und Techniken (10.Aufl.). Weinhheim: Beltz.

Meyer, T. (2005). An der zweiten Schwelle: Junge Menschen im Übergang zwischen Ausbildung und Arbeitsmarkt, Ergebnisübersicht des Jugendlängsschnitts TREE, Stand 2004. Bern.

Meyer, T. (2009): Wie geht es weiter nach der Schule? Uni Nova Wissenschaftsmagazin der Universität Basel, 112, 6.

Moser, U. (2004). Jugendliche zwischen Schule und Berufsbildung. Eine Evaluation bei Schweizer Grossunternehmen unter Berücksichtigung des internationalen Schulleistungsvergleichs PISA. Bern: h.e.p. verlag ag.

Mücher, F. (2010). Prekäre Hilfen? Soziale Arbeit aus Sicht wohnungsloser Jugendlicher. Wiesbaden: Verlag für Sozialwissenschaften.

Nadai, E. (2013). Aktivierung. In A. M. Riedi, M. Zwilling, M. Meier Kressig, P. Benz Bartoletta, \& D. Aebi Zindel (Eds.), Handbuch Sozialwesen Schweiz (pp. 332335). Bern: Haupt Verlag.

Nationale IIZ Koordinationsgruppe. (2004). Handbuch zur Interinstitutionellen Zusammenarbeit (IIZ). Bern: Seco - Direktion für Arbeit

Organisation for Economic Cooperation and Development (OECD). (2013). Youth unemployment rate (\% of youth labour force (15-24). Retrieved from: http://www.oecd-ilibrary.org/employment/youth-unemployment-rate_20752342table2

Schaffner, D. (2007). Junge Erwachsene zwischen Sozialhilfe und Arbeitsmarkt. Biographische Bewältigung von diskontinuierlichen Bildungs- und Erwerbsverläufen. Bern: h.e.p verlag.

Schaffner, D., \& Drilling, M. (2013). Junge Erwachsene in der Sozialhilfe. Folgen veränderter Bedingungen am Übergang in die Erwerbsarbeit. In E. M. Piller \& S. 
International Journal of Child, Youth and Family Studies (2015) 6(3): 478-493

Schnurr (Eds.), Kinder und Jugendhilfe in der Schweiz (pp. 297-330). Wiesbaden: Springer Fachmedien.

Schaffner, D., \& Gerber, S. (2014). Armutsrisiken bei jungen Erwachsenen. Massnahmen im Spannungsfeld von Beschäftigungsfähigkeit und biographischer Handlungsfähigkeit. In S. Voélin, M. Eser Davolio, \& M. Lindenau (Eds.), Le travail social entre résistance et innovation. Soziale Arbeit zwischen Widerstand und Innovation (pp. 199-206). Genève/Luzern: interact Verlag.

Schultheis, F., Perrig-Chiello, P., \& Egger, S. (Eds.). (2008). Kindheit und Jugend in der Schweiz. Ergebnisse des Nationalen Forschungsprogramms, "Kindheit, Jugend und Generationenbeziehungen im gesellschaftlichen Wandel”. Weinheim und Basel: Beltz Verlag.

Schweizerische Koordinationsstelle für Bildungsforschung. (2014). Bildungsbericht Schweiz. Retrieved from: http://www.skbfcsre.ch/fileadmin/files/pdf/bildungsmonitoring/epaperbildungsbericht2014de/index.htmlf

Schweizer Medieninstitut für Bildung und Kultur. (2011). The Swiss education system. Retrieved from http://swisseducation.educa.ch/en/swiss-education-system-5

Stadt Zürich. (2014): Sozialhilfe. Retrieved from: http://www.stadtzuerich.ch/content/sd/de/index/beratung/sozialhilfe.html

Suter, C., \& Höpflinger, F. (2008). Intergenerationelle Vermittlung von Bildung und Status. In P. Perrig-Chiello, F. Höpflinger, \& C. Suter (Eds.), Generationen Strukturen und Beziehungen. Generationenbericht Schweiz.Synthesebericht des Nationalen Forschungsprogramms 52 "Kindheit, Jugend und Generationenbeziehungen in einer sich wandelnden Gesellschaft” (pp. 135-144). Zürich: Seismo Verlag.

UNESCO. (1960). Convention against discrimination in education, adopted by the General Converence at its 11th session, Paris, December 14, 1960.

United Nations. (2014). The universal declaration of human rights. Retrieved from: http://www.un.org/en/documents/udhr/\#atop

Wolf, A. (2011). Wohnungslosigkeit. In H. U. Otto \& H. Thiersch (Eds.), Handbuch Soziale Arbeit. Grundlagen der Sozialarbeit und Sozialpädagogik, 4. völlig neu bearbeitete Auflage (pp. 1756-1764). München Basel: Ernst Reinhardt Verlag. 